\title{
Procedural Prerequisites to Private Suit Under the Age Discrimination in Employment Act
}

The Age Discrimination in Employment Act of $1967^{1}$ (ADEA) is designed to promote the employment of older persons ${ }^{2}$ by prohibiting employers from making hiring decisions based on arbitrary discrimination against age. ${ }^{3}$ The substantive provisions ${ }^{4}$ are enforceable both by governmental actions ${ }^{5}$ and by private suits brought by persons who have been injured under the terms of the statute. ${ }^{6}$ The Act requires the Secretary of Labor to seek elimination of the allegedly discriminatory practice "through informal methods of conciliation, conference and persuasion"7 before formal adversary proceedings can be instituted. In order to provide time to attempt this conciliation, an aggrieved individual is required to notify the Secretary that he intends to sue sixty days before bringing an action. ${ }^{8}$

Two additional procedural requirements imposed by the Act on private litigants have been the subjects of conflicting judicial interpretation and application. Section $626(d)(1)$ requires that the sixtyday notice of intent to sue be filed with the Secretary within 180 days after the allegedly discriminatory act occurred. ${ }^{9}$ Section 633 ,

' 29 U.S.C. $\$ \S 621-634$ (1970).

2 The Act extends protection to persons aged 40-64. Id. \& 631 .

3 The Act is also designed to promote the education of employers and the general public as to the employment capabilities of older persons. Id. $\$ 622$.

- The specific prohibitions are enumerated at id. §623. Pursuant to $\$ 623(\mathrm{c})$, labor unions are under the same obligations as employers.

${ }^{3}$ Section 626(b) of the ADEA authorizes suits by the Secretary of Labor in accordance with the provisions of $\S \S 16$ (c) \& 17 of the Fair Labor Standards Act, 29 U.S.C. $\S \S 216$ (c), 217 (1970).

- Id. $\S \S 626$ (b), (c) (1970). The $\S 626$ (b) action is to be brought according to the provisions of $\S 16$ (b) of the Fair Labor Standards Act, 29 U.S.C. $\S 16$ (b) (Supp. IV 1974).

'Id. $\S 626(\mathrm{~d})$. See also id. $\S \S 621(\mathrm{~b}), 626(\mathrm{~b})$, which make it clear that the Act is designed to promote informal conciliation of disputes whenever possible. The congressional policy of promoting voluntary compliance is also reflected in the design of Title VII of the Civil Rights Act of 1964, 42 U.S.C. $\$ \S 2000$ e to 2000 e-17 (1964). See Developments in the Law-Employment Discrimination and Title VII of the Civil Rights Act of 1964, 84 HARv. L. REv. 1109, 1195-99 (1971).

29 U.S.C. $\$ 626(d)(1970)$.

- 29 U.S.C. $\$ 626(d)$ (1970) provides:

No civil action may be commenced by any individual under this section until the individual has given the Secretary not less than sixty days' notice of an intent to file such action. Such notice shall be filed-

(1) within one hundred and eighty days after the alleged unlawful practice occurred, or 
the "federal-state relationship" provision, forbids a private ADEA suit until sixty days after the commencement of any proceedings instituted under a state age discrimination act. ${ }^{10}$

Most courts that have considered the 180-day notice requirement have characterized it as a jurisdictional prerequisite to private suit under the ADEA. ${ }^{11}$ Courts have not, however, agreed on the consequences of this characterization. Several courts have suggested that they have the power to toll or waive the requirement even though it is "jurisdictional."12 Recently, the Tenth Circuit in Dartt v. Shell Oil Co. ${ }^{13}$ rejected the jurisdictional characterization and held that the requirement is analogous to a statute of limitations, thus allowing courts to invoke equitable modifications such as tolling and estoppel. ${ }^{14}$

(2) in a case to which section 633(b) of this title applies, within three hundred days after the alleged unlawful practice occurred or within thirty days after receipt by the individual of notice of termination of proceedings under State law, whichever is earlier.

Upon receiving a notice of intent to sue, the Secretary shall promptly notify all persons named therein as prospective defendants in the action and shall promptly seek to eliminate any alleged unlawful practice by informal methods of conciliation, conference, and persuasion.

10 29 U.S.C. $\S 633$ (1970) provides:

(a) Nothing in this chapter shall affect the jurisdiction of any agency of any State performing like functions with regard to discriminatory employment practices on account of age except that upon commencement of action under this chapter such action shall supersede any State action.

(b) In the case of an alleged unlawful practice occurring in a State which has a law prohibiting discrimination in employment because of age and establishing or authorizing a State authority to grant or seek relief from such discriminatory practice, no suit may be brought under section 626 of this title before the expiration of sixty days after proceedings have been commenced under the State law unless such proceedings have been earlier terminated.....

"See Ott v. Midland-Ross Corp., 523 F.2d 1367 (6th Cir. 1975); Hiscott v. General Elec. Co., 521 F.2d 632 (6th Cir. 1975); Edwards v. Kaiser Aluminum \& Chem. Sales, Inc., 515 F.2d 1195 (5th Cir. 1975); Powell v. Southwestern Bell Tel. Co., 494 F.2d 485 (5th Cir. 1974); Brohl v. Singer Co., 407 F. Supp. 936 (M.D. Fla. 1976); Raynor v. Great Atl. \& Pac. Tea Co., 400 F. Supp. 357 (E.D. Va. 1975); Vaughn v. Chrysler Corp., 382 F. Supp. 143 (E.D. Mich. 1974); Oshiro v. Pan Am. World Airways, Inc., 378 F. Supp. 80 (D. Hawaii 1974); Gebhard v. GAF Corp., 59 F.R.D. 504 (D.D.C. 1973); Burgett v. Cudahy Co., 361 F. Supp. 617 (D. Kan. 1973); Cochran v. Ortho Pharmaceutical Corp., 376 F. Supp. 302 (E.D. La. 1971).

12 See Edwards v. Kaiser Aluminum \& Chem. Sales, Inc., 515 F.2d 1195 (5th Cir. 1975) (dictum suggesting that the period may be tolled); McCrickard v. Acme Visible Records, 409 F. Supp. 341, 343 (W.D. Va. 1976) ("While courts have taken different viewpoints as to the appropriate severity to invoke in applying this provision, the majority view appears to be that the requirement is jurisdictional and should not be overlooked lightly."); Bishop v. Jelleff Assocs., Inc., 398 F. Supp. 579 (D.D.C. 1974) (suggesting period may be waived); Price v. Maryland Cas. Co., 5 Empl. Prac. Dec. 6662 (E.D. Miss. 1972) (suggesting period may be waived by the consent of defendant).

i3 539 F.2d 1256 (10th Cir. 1976), cert. granted, 97 S.Ct. 1097 (1977).

"Id. at $1260-61$. 
Judicial interpretations of the federalism provision of the ADEA have also been inconsistent. It is unclear whether section 633 requires an aggrieved individual initially to file a complaint with the appropriate state authorities ${ }^{15}$ or simply provides the state authorities sixty days to handle complaints that have been brought to them voluntarily. ${ }^{16}$ Courts that have held that the section requires initial state filing have disagreed as to whether this is a jurisdictional prerequisite to suit. ${ }^{17}$ Courts that interpret the requirement to make state filing elective must determine whether section 626(d)(2) of the Act, which modifies the period for notifying the Secretary of the intention to sue "in a case to which section 633(b) . . . applies,"18 affects all private complainants in states with age discrimination laws or only those who have filed state complaints.

This comment explores the conflicting interpretations of these sections and suggests resolutions.

\section{Section 626(d)(1)}

A. The Nature of the Problem: Characterizing Procedural Time Requirements

The basic controversy surrounding the 180 -day notice requirement of section 626(d)(1) is whether it is a jurisdictional prerequisite to suit, or analogous to a statutue of limitations. ${ }^{19}$ If the section is viewed as a jurisdictional prerequisite, a plaintiff's failure to com-

is See Curry v. Continental Airlines, 513 F.2d 691 (9th Cir. 1975); Goger v. H.K. Porter Co., 492 F.2d 13 (3d Cir. 1974); Smith v. Crest Communities, Inc., 9 Empl. Prac. Dec. 7334 (W.D. Ky. 1974).

When the section is interpreted to mandate state filing, the court must determine what characteristics a state law must possess before the section requires filing. See Garces v. Sagner Int'l Inc., 534 F.2d 987 (1st Cir. 1976); Eklund v. Lubrizol Corp., 529 F.2d 247 (6th Cir. 1976); Curry v. Continental Airlines, 513 F.2d 691 (9th Cir. 1975); Hadfield v. Mitre Corp., 422 F. Supp. 460 (D. Mass. 1976); Bertrand v. Orkin Exterminating Co., 419 F. Supp. 1123 (N.D. Ill. 1976); Vazquez v. Eastern Airlines, Inc., 405 F. Supp. 1353 (D.P.R. 1975).

1" See Bertrand v. Orkin Exterminating Co., 419 F. Supp. 1123 (N.D. II. 1976); Smith v. Jos. Schlitz Brewing Co., 419 F. Supp. 770 (D.N.J. 1976); Vazquez v. Eastern Airlines, Inc., 405 F. Supp. 1353 (D.P.R. 1975); Skoglund v. Singer Co., 403 F. Supp. 797 (D.N.H. 1975).

1 Compare Skoglund v. Singer Co., 403 F. Supp. 797 (D.N.H. 1975) (requirement not jurisdictional) with Goger v. H.K. Porter Co., 492 F.2d 13 (3d Cir. 1974).

is 29 U.S.C. $\$ 626(d)(2)$ (1970); see note 9 supra.

"See text and notes at notes 11-14 supra. The problem of determining whether a procedural requirement goes to the jurisdiction of the court is not unique to the ADEA. See, e.g., Fauntleroy v. Lum, 210 U.S. 230 (1908). In Fauntleroy, Mr. Justice Holmes wrote: "Whether a given statute is intended simply to establish a rule of substantive law, and thus to define the duty of the court, or is meant to limit its power, is a question of construction and common sense." Id. at 235. See also Burnet v. Desmornes, 226 U.S. 145 (1912) (Holmes, J.). 
ply in theory results in an absolute bar to suit..$^{20}$ Because a jurisdictional defect destroys a court's power to hear a case, ${ }^{21}$ a court cannot examine the circumstances surrounding a plaintiff's noncompliance to determine whether equitable considerations warrant keeping the suit alive. ${ }^{22}$ By contrast, noncompliance with a statute of limitations does not end judicial power to hear the case; a residuum of equitable power remains. ${ }^{23} \mathrm{~A}$ court can review the circumstances surrounding the plaintiff's noncompliance and decline to dismiss the case by finding, for example, that the limitation period has been tolled, ${ }^{24}$ or that the defendant's conduct estops him from invoking the expired time limit as an affirmative defense. ${ }^{25} \mathrm{~A}$ court might also find that the defendant has waived the statute of limitations. ${ }^{26}$ In short, time

${ }^{20}$ See text and note at note 12 supra.

${ }^{21}$ Federal courts, other than the Supreme Court, "have only that jurisdiction which Congress, acting within the limits of the Constitution, confers upon them." 1 MOORE's FEDERAl Practice T 0.60, at 608 (2d ed. 1976). The limit on jurisdiction is clear: "[i]f there is no statutory grant, federal jurisdiction is lacking, for . . . parties cannot confer jurisdiction upon a federal court by consent." Id. I $0.60[2]$, at 605 . A jurisdictional prerequisite to suit is an absolute requirement because, if the plaintiff fails to comply with its terms, a condition of the statutory grant of jurisdiction fails. If at any time during proceedings on a case, the court discovers that the conditions upon its jurisdiction have not been met, it must dismiss the case. Fen. R. CIv. P. 12(h)(3).

2 Federal courts do have a limited flexibility in applying jurisdictional prerequisites, stemming from their power to determine their own jurisdiction. See, e.g., United States v. United Mine Workers of America, 330 U.S. 258 (1947); United States v. Shipp, 203 U.S. 563 (1906). For example, in the case of time limits, courts have a certain flexibility in determining when the time period began to run. See, e.g., Urie v. Thompson, 337 U.S. 163 (1949); Quinton v. United States, 304 F.2d 234 (5th Cir. 1962). Although this flexibility strays close to equitable power, a court is limited to determining whether there has been compliance and may not openly excuse noncompliance on equitable grounds. But see text and note at note 12 supra.

${ }^{23}$ Once a statute of limitations has run, the individual loses his ability to invoke "the public power in support of an otherwise valid claim." Developments in the Law-Statutes of Limitations, 63 HARv. L. REv. 1177, 1185 (1950) [hereinafter cited as Developments]. However, noncompliance with a statute of limitations must be raised by the defendant as an affirmative defense; failure to raise the defense constitutes a waiver. FED. R. Crv. P. 12(h)1. As a result of the possibility of waiver, parties to an action may agree not to plead the limitations period. Cf. United States v. Wild, 551 F.2d 418 (D.C. Cir. 1977) (a statute of limitations in a criminal statute may be waived by criminal defendant). This is in marked contrast to the parties' inability to confer subject matter jurisdiction upon a federal court by consent. See note 21 supra. Moreover, even when the defendant raises the running of the limitations period as a defense, the court has equitable power to excuse the plaintiff's untimeliness. See text and notes at notes 24-26 infra.

24 A court may toll the time period where, for example, the defendant fraudulently conceals his wrong from the plaintiff, or the wrong is of such a nature that it tends to conceal itself. See, e.g., Bailey v. Glover, 88 U.S. (21 Wall.) 342, 349-50 (1874).

${ }^{25}$ A defendant is estopped from raising the running of the period when he induces the plaintiff to forbear from filing suit until the period has run. See Developments, supra note 23 , at 1222 .

${ }^{26}$ See note 23 supra; Dawson, Estoppel and Statutes of Limitation, 34 Mich. L. REv. 1 (1935). 
limits characterized as jurisdictional prerequisites entail a single question: was there compliance? Time limits characterized as statutes of limitations entail a further question: does the explanation for noncompliance justify the court's use of its equitable power to maintain the suit?

One way to determine whether a time requirement such as that in section $626(d)(1)$ should be characterized as jurisdictional or as a statute of limitations is to appeal to principles of statutory construction. One such principle has been traditionally employed to distinguish two categories of statutes of limitations: "substantive" statutes that are not subject to equitable modification, and "procedural" statutes that are. ${ }^{27}$ This principle characterizes time limits as substantive if they are contained in the same act that created the right sought to be enforced, on the ground that such limitations are conditions upon that right and therefore absolute. ${ }^{28}$ The running of a substantive time limit extinguishes the underlying right. Procedural time limits, on the other hand, are held to affect only the remedy and not the right..$^{29}$ They are thus subject to the traditional equitable doctrines of tolling, estoppel, and waiver. ${ }^{30}$ This principle of statutory construction is based on a presumption that the legislature meant noncompliance with time limits included in the body of a statute to preclude judicial tolling of the time limit or application of estoppel doctrine.

The Supreme Court, in Burnett v. New York Central Railroad, ${ }^{31}$ repudiated this mechanical principle and held that courts must determine whether Congress actually intended the time limit to be absolute or to be subject to equitable principles. In order to determine Congress's intent, the courts must examine the purposes and policies underlying the limitations provisions, the statute in which they appear, and the remedial scheme developed for en(1941).

"7 Developments, supra note 23, at 1186-88; 34 AM. JuR. Limitation of Actions $\$ 187$

${ }^{28}$ Developments, supra note 23 , at 1188 . Substantive statutes of limitations and jurisdictional prerequisites appear to be functional equivalents, in that neither is subject to tolling or estoppel. However, because a substantive time limit is a statute of limitations, it must be raised as a defense and therefore may be waived. See id. at 1199. A substantive statute of limitations cannot be said to go to the subject matter jurisdiction of the courts, as does a jurisdictional prerequisite. See note 23 supra.

27 Developments, supra note 23, at 1186-87, 1234.

${ }^{30}$ See notes 24-25 supra. A time period is waived when the defendant agrees, either expressly or implicitly, not to raise the period as a defense. See note 23 supra. See also Dawson, supra note 26, at 11 (suggesting that the better conceptualization of waiver is "estoppel").

31 380 U.S. 424 (1965). 
forcing the statutory rights. " "[T] he basic question . . . is one of legislative intent whether the right shall be enforceable . . . after the prescribed time." ${ }_{33}$ The Court reiterated this position in American Pipe \& Construction Co. v. Utah, ${ }^{34}$ citing with approval an earlier case in which it had rejected the contention that when "the time limitation is an integral part of a new cause of action . . . that cause is irretrievably lost at the end of the stautory period." ${ }_{35}$

Burnett and American Pipe addressed the authority of the courts to toll time limitations that have already been characterized as statutes of limitations. But the reasoning of these cases and their rejection of any mechanical test also apply to the prior question whether a given time limit is jurisdictional or analogous to a statute of limitations. ${ }^{36}$ If nothing short of the thorough analysis demanded by Burnett and American Pipe is sufficient to establish the character of a statute of limitations, no less demanding or more mechanical approach should suffice for determining whether a time requirement is jurisdictional or not. Under the rationale of those cases, the critical question for determining how to characterize section

32 Id. at 427 .

${ }^{3}$ Id. at 426 (citations omitted).

3 414 U.S. 538 (1974).

${ }^{35}$ Id. at 559, quoting Glus v. Brooklyn E. Dist. Terminal, 359 U.S. 231, 232 (1959).

${ }^{36}$ In at least one case arising under the ADEA, Skoglund v. Singer Co., 403 F. Supp. 797 (D.N.H. 1975), the court thought it necessary to rebut the argument that "where statutory rights are asserted in a court, strict compliance with the statute in question is a jurisdictional prerequisite to the commencement of a civil action based upon that statute." Id. at 801, quoting McGarvey v. Merck \& Co., 359 F. Supp. 525, 528 (D.N.J. 1973), vacated, 493 F.2d 1401 (3d Cir. 1974), cert. denied, 414 U.S. 836 (1975); accord, Abshire v. Chicago \& E. IIl. R.R., 352 F. Supp. 601, 604-05 (N.D. Ill. 1972). This principle is traceable to Scott v. Railroad Retirement Bd., 227 F.2d 684, 686 (7th Cir. 1955), which in turn relied upon Matheny v. Porter, 158 F.2d 478 (10th Cir. 1946). According to the Seventh Circuit in Scott, the Tenth Circuit in Matheny had "pointed out the distinction between an ordinary statute of limitation and a limitation found in the statute which created the right of action, and explained that, on the expiration of the time to sue fixed in the statute creating the right, the right of action itself is extinguished." $227 \mathrm{~F} .2 \mathrm{~d}$ at 686 . This is the very principle that the Supreme Court rejected in Burnett and American Pipe. Furthermore, the Tenth Circuit in Matheny explicitly derived its premises from the case of The Harrisburg, 119 U.S. 199 (1886), which case the Supreme Court first in Burnett, then in American Pipe, explained was the genesis of the unsound distinction between procedural and substantive statutes of limitations. Burnett v. New York Cent. R.R., 380 U.S. 424, 427 n.2 (1965); American Pipe \& Constr. Co. v. Utah, 414 U.S. 538, 556. (1974). This suggests that there is a historical connection between the conflicting doctrines of statutory construction that faced the Supreme Court in Burnett and American Pipe and the conflicting doctrines confronting courts construing the requirements of the ADEA. The reasoning in Burnett and American Pipe is pertinent to the problems surrounding the construction of the ADEA time requirements despite the fact that these cases involved problems of characterizing time limits already assumed to be statutes of limitations, while the problem presented by the ADEA is to determine whether its time requirements are "jurisdictional" or analogous to statutes of limitations. 
626(d)(1) is what consequences Congress intended should follow from noncompliance with its time limit, based on an analysis of the scheme and purposes of the ADEA.

\section{B. The Procedural Scheme of the ADEA and the Judicial Approach}

Section 626(d) of the ADEA provides in part that

No civil action may be commenced by any individual . . . until the individual has given the Secretary not less than sixty days' notice of an intent to file such action. Such notice shall be filed-

(1) within one hundred and eighty days after the alleged unlawful practice occurred . . . .37

A major purpose of this scheme is to provide the Secretary of Labor with an opportunity to avert litigation by attempting an informal settlement. ${ }^{38}$ The requirement that an individual who intends to sue his employer for violations of the ADEA must notify the Secretary is uniformly viewed as a jurisdictional prerequisite to suit. ${ }^{39}$ To construe the notice requirement in any other manner would frustrate the scheme's purpose by inducing plaintiffs to apply directly to the courts for determination of the need to resort to informal procedures.

The courts have also uniformly held that the requirement that the Secretary have sixty days in which to attempt an informal resolution of the dispute is jurisdictional. ${ }^{40}$ In effect, the courts view these two elements of the scheme as a single jurisdictional prerequisite to suit. ${ }^{11}$ However, the problem remains whether the third element of the scheme, the 180-day time limit, is separable from the jurisdictional requirement of sixty days' notice and therefore analyzable independently in the manner suggested by Burnett and American Pipe.

ग 29 U.S.C. \& 626(d) (1970).

ss H.R. REP. No. 805, 90th Cong., 1st Sess. (1967), reprinted in [1967] U.S. CodE Cong. \& AD. NEws 2213, 2218; Burgett v. Cudahy Co., 361 F. Supp. 617, 621 (D. Kan. 1973).

39 Dartt v. Shell Oil Co., 539 F.2d 1256 (10th Cir. 1976), cert. granted, 97 S. Ct. 1097 (1977); Hiscott v. General Elec. Co., 521 F.2d 632 (6th Cir. 1975); Edwards v. Kaiser Alum. \& Chem. Sales, Inc., 515 F.2d 1195 (5th Cir. 1975); Powell v. Southwestern Bell Tel. Co., 494 F. 2d 485 (5th Cir. 1974); Raynor v. Great Atl. \& Pac. Tea Co., 400 F. Supp. 357 (E.D. Va. 1975); Vaughn v. Chrysler Corp., 382 F. Supp. 143 (E.D. Mich. 1974); Oshiro v. Pan Am. World Airways, Inc., 378 F. Supp. 80 (D. Hawaii 1974); Gebhard v GAF Corp., 59 F.R.D. 504 (D.D.C. 1973); Burgett v. Cudahy Co., 361 F. Supp. 617 (D. Kan. 1973); Cochran v. Ortho Pharmaceutical Corp., 376 F. Supp. 302 (E.D. La. 1971).

${ }^{10}$ See note 39 supra.

"See note 39 supra. 
Most courts that have considered the requirement that the Secretary be notified within 180 days after the alleged discrimination occurred have concluded that compliance with this time limit is a jurisdictional prerequisite to suit. ${ }^{42}$ These courts characteristically treat the requirement as an inseparable aspect of the notice requirement, basing their conclusion on the legislative history of the ADEA, analogies to Title VII precedent, and a functional analysis of the Act. However, a recent case has examined the same sources and treated the requirement as independent of the notice prerequisite. ${ }^{43}$

1. The Legislative History. The ADEA's legislative history has proven unsatisfactory as a guide for interpreting section 626(d)(1). The 180-day time limit was part of the original Senate bill, 44 then was deleted by the House of Representatives ${ }^{45}$ and finally was restored as one of several amendments to the bill as enacted. ${ }^{46}$ Although few congressional statements mark this process, some courts have attempted to infer a clear legislative intent.

In Powell v. Southwestern Bell Telephone Co., ${ }^{47}$ the Fifth Circuit rejected a contention that the legislative history of section 626(d) supported the proposition that the 180-day limit was "merely directory" rather than "jurisdictional in nature." ${ }_{48}$ Noting that nothing in the legislative history "addresses the precise question," 49 the court found "some support for, if anything," construing the 180day time limit as jurisdictional..$^{50}$ Focusing on House Report No. $805,{ }^{51}$ which discussed the "companion requirement" of the sixtyday waiting period after a notice of intent to sue had been filed, the

12 See Ott v. Midland-Ross Corp., 523 F.2d 1367 (6th Cir. 1975); Hiscott v. General Elec. Co., 521 F.2d 632 (6th Cir. 1975); Edwards v. Kaiser Alum. \& Chem. Sales, Inc., 515 F.2d 1195 (5th Cir. 1975); Powell v. Southwestern Bell Tel. Co., 494 F.2d 485 (5th Cir. 1974); Raynor v. Great Atl. \& Pac. Tea Co., 400 F. Supp. 357 (E.D. Va. 1975); Vaughn v. Chrysler Corp., 382 F. Supp 143 (E.D. Mich. 1974); Oshiro v. Pan Am. World Airways, Inc., 378 F. Supp. 80 (D. Hawaii 1974); Gebhard v. GAF Corp., 59 F.R.D. 504 (D.D.C. 1973); Burgett v. Cudahy Co., 361 F. Supp. 617 (D. Kan. 1973); Cochran v. Ortho Pharmaceutical Corp., 376 F. Supp. 302 (E.D. La. 1971).

${ }^{3}$ Dartt v. Shell Oil Co., 539 F.2d 1256 (5th Cir. 1976), cert. granted, 97 S. Ct. 1097 (1977).

" S. 830, 90th Cong., 1st Sess. (1967), reprinted in [1967] U.S. Cone Cong. \& AD. News $2213,2218$.

is H.R. 13054, 90th Cong., 1st Sess. (1967); 113 Cong. REc. 34,738 (1967).

46 The House concurred in the amendment. 114 CoNG. REC. 35,133 (1967).

17494 F.2d 485 (5th Cir. 1974).

4 Id. at 488.

Id.

so Id.

31 H.R. Rep. No. 805, 90th Cong., 1st Sess. (1967), reprinted in [1967] U.S. CoNG. \& AD. News 2213, 2218; Burgett v. Cudahy Co., 361 F. Supp. 617, 621 (D. Kan. 1973). 
court noted that Congress had "characterized the notice as a 'condition precedent' to filing." 52 Without further analysis, the court found that a "permissible inference is that the requirement of timeliness attending notice is likewise a condition precedent to suit." 53

The basis of this inference is unclear. The 180-day limit, which was absent from the House version of the bill, ${ }^{54}$ was not mentioned in the House report that the Fifth Circuit examined..$^{55}$ The court did note that the same House report had stated that "persons intending to file [suit] must give the Secretary . . .60 days' notice . . . ," 60 and "[m]ore to the point," the Senate report on the bill"s7 had used the same mandatory language with regard to the 180-day time limit. ${ }^{58}$ One appearance of such mandatory language in a congressional report is an insufficient basis for interpreting an ambiguous statute. ${ }^{59}$ The court sought further support for characterizing the time limit as jurisdictional in a statement by Senator Javits, a proponent of the Senate amendments, to the effect that the limit was restored "together with several other portions of the original Senate bill," in order "to answer some of the disquiet in American business . . . ." ${ }_{60}$ The court infers from these remarks that only a 180-day jurisdictional prerequisite to suit would calm the "disquiet in ... . business"; characterizing the time limit as a statute of limitations would not suffice. The record does not disclose the

32494 F.2d at 488 .

sd.

34 H.R. 13054, 90th Cong., 1st Sess., 113 Cong. REc. 34,738 (1967).

ss H.R. REP. No. 805, 90th Cong., 1st Sess. (1967), reprinted in [1967] U.S. Cong. \& AD. News 2213, 2218; Burgett v. Cudahy Co., 361 F. Supp. 617, 621 (D. Kan. 1973).

st 494 F.2d at 488, quoting H.R. REP. No. 805, 90th Cong., 1st Sess. (1967).

7 S. REP. No. 723, 90th Cong., 1st Sess. (1967).

ss 494 F.2d at 488.

3) Caution is required in drawing inferences as to the mandatory or directory character of a statutory provision on the basis of language actually contained in the statute.

[I]t is important to keep in mind the sense in which the terms mandatory [jurisdictional] and directory [nonjurisdictional, e.g., statutes of limitations] are used, that they are only descriptive of the effect that it has been decided should be given to a statutory provision, and that there is no essential difference in statutes whereby their mandatory or directory character can be identified as a means to determining their effect. No statutory provisions are intended by the legislature to be disregarded; but where the consequences of not obeying them in every particular are not prescribed, the courts must judicially determine them.

J. Sutherland, Statutes and Statutory Construction $\S 57.01$ (4th ed. C. Sands 1973). Even more caution is necessary where the imperative language is found not in the language of the statute, but only in the legislative history. Interestingly, \$626(d) does not use the word "must," but rather the word "shall." If anything, "shall" is less imperative than "must"; in either case, the terminology is not dispositive where there are other factors to consider. Id. ch. 57 .

w 494 F.2d at 488, citing 113 Cong. Rec. 35,056 (1967) (remarks of Senator Javits). 
precise nature of the concerns of the business sector, and the general nature of Senator Javits's remarks makes them poor support for the court's interpretation. Conceivably, the business sector would have been or was satisfied with the addition of a statute of limitations where none had previously existed.

The analysis in Powell demonstrates the limitations of searching the sparse legislative history for evidence of congressional intent. Furthermore, Powell rests on the assumption, never explained, that the admittedly jurisdictional notice and sixty-day waiting period requirements are "companion" to the 180 -day time limit. .1

In Dartt v. Shell Oil Co. ${ }^{62}$ the Tenth Circuit rejected this assumption and examined the legislative history for indications that the 180-day period, apart from the notice of intent to sue requirement, was jurisdictional. The court found nothing to convince it "that Congress intended the failure to file notice within the one hundred and eighty day notice period to be an absolute bar to bringing an ADEA private action." 63 The Dartt Court's more specific investigation is more in line with the thorough analysis that Burnett and American Pipe suggest is necessary to characterize properly a procedural time requirement, and the court's findings demonstrate that the legislative history simply provides no reliable guide.

2. Title VII Precedent. The courts faced with the problem of construing the ADEA have looked to Title VII precedent for guidance. Although the statutes are historically linked ${ }^{64}$ and share many similar provisions, ${ }^{65}$ the examination of Title VII precedent, like the legislative history of the ADEA, has provided little assistance. The Tenth Circuit in Dartt partially based its conclusion that the 180day time limit is not jurisdictional on three Title VII cases. ${ }^{66} \mathrm{In}$

"Id.

62539 F.2d 1256 (10th Cir. 1976), cert. granted, 97 S. Ct. 1097 (1977).

63 Id. at 1259.

"U Under $\S 715$ of Title VII, 42 U.S.C. $\$ 2000 \mathrm{e}-14$ (1970), the Secretary of Labor was required to undertake a study of age discrimination in employment and to supply Congress with specific legislative recommendations. The Secretary's report, The Older American Worker: Age Discrimination in Employment, H.R. REP. No. 3708, 89th Cong., 1st Sess. (1965), and his legislative recommendations formed the basis of the ADEA.

${ }^{\text {es }}$ Compare 29 U.S.C. $\$ \S 623,630$ (1970) (ADEA substantive provisions) with 42 U.S.C. $\S \S 2000 \mathrm{e}-2$, 2000e (1970); compare 29 U.S.C. $\$ \S 211$ (b), 216(c), 217, 626(b), 633 (1970) (ADEA enforcement provisions) with 42 U.S.C. $\$ 2000$ e-5 (1970). For arguments that Title VII precedent should not be automatically applied to ADEA cases, see Note, The Age Discrimination in Employment Act of 1967, 90 HaRv. L. Rev. 380 (1976).

86 539 F.2d at 1259-60, citing Reeb v. Economic Opportunity Atlanta, Inc., 516 F.2d 924 (5th Cir. 1975); Culpepper v. Reynolds Metals Co., 421 F.2d 888 (5th Cir. 1970); Antonopulos v. Aerojet-General Corp., 295 F. Supp. 1390 (E.D. Cal. 1970). 
Cochran v. Ortho Pharmaceutical Co. ${ }^{67}$ the district court cited three different Title VII cases to support the opposite result. ${ }^{68}$ The Fifth Circuit in Powell denied that the requirements of the ADEA can be profitably compared with those of Title VII. ${ }^{69}$ These conflicting uses of Title VII precedent reflect both structural differences between the ADEA and Title VII and the unsettled state of Title VII interpretation.

The enforcement mechanisms of the ADEA, while similar to those of Title VII, are less complex, ${ }^{70}$ reflecting a congressional desire to avoid some of the administrative logjams experienced under Title VII. ${ }^{11}$ Neither act permits complainants to have direct access to the courts; aggrieved individuals must file initial complaints with an agency of the federal government. ${ }^{72}$ Under Title VII, the complaint must be filed within 180 days after the alleged violation. ${ }^{73}$ In language nearly identical to that of section $633(\mathrm{~b})$ of the ADEA, ${ }^{74}$ section $2000 \mathrm{e}-5$ (c) of Title $\mathrm{VII}^{75}$ provides that no charge may be filed with the EEOC before the expiration of sixty days from the commencement of state or local proceedings, unless those proceedings

376 F. Supp. 302 (E.D. La. 1971).

ss Id. at 303 n.6, citing Boudreaux v. Baton Rouge Marine Contracting Co., 437 F.2d 1011 (5th Cir. 1971); Georgia Power Co. v. EEOC, 412 F.2d 462 (5th Cir. 1969); Choate v. Caterpillar Tractor Co., 402 F.2d 357 (7th Cir. 1969).

" The court reasoned that the time limit on filing a charge under Title VII was open to judicial interpretation because it is not contained in the section of the Act which limited the filing of civil actions. But the 180-day period of the ADEA is not open to interpretation because it is contained in the section that expressly deals with time limits on civil actions. The court concluded that it was "abundantly clear" that the ADEA requirement is jurisdictional. 494 F.2d at 488.

7 For general discussions of procedure under Title VI, see Comment, Jurisdictional Prerequisites to Private Actions under Title VII of the Civil Rights Act of 1964, 41 Mo. L. REv. 215 (1976); Developments in the Law-Employment Discrimination and Title VII of the Civil Rights Act of 1964, 84 HARv. L. REv. 1109 (1971).

"See 113 CoNG. REc. 7076 (1976) (testimony of Sen. Javits before the Subcommittee on Labor of the Committee on Labor and Public Welfare).

7242 U.S.C. $\$ 2000 \mathrm{e}-5$ (a) (1970); 29 U.S.C \& 626 (1970).

7342 U.S.C. $\$ 2000 \mathrm{e}-5$ (e) (Supp. III 1973) (amending 42 U.S.C. $\$ 2000 \mathrm{e}-5$ (d) (1970) (90day period)).

"See note 10 supra.

7342 U.S.C. § 2000e-5(c) (Supp. III 1973) provides:

In the case of an alleged unlawful employment practice occurring in a State, or political subdivision of a State, which has a State or local law prohibiting the unlawful employment practice alleged and establishing or authorizing a State or local authority to grant or seek relief from such practice or to institute criminal proceedings with respect thereto upon receiving notice thereof, no charge may be filed under subsection (b) of this section by the person aggrieved before the expiration of sixty days after proceedings have been commenced under the State or local law, unless such proceedings have been earlier terminated, provided that such sixty-day period shall be extended to one hundred and twenty days during the first year after the effective date of such State or local law . . . . 
have terminated earlier. However, it is less complicated for an individual to bring his case to court after the initial filing of his complaint under the ADEA than it is under Title VII. Under the ADEA, the aggrieved individual may bring suit when the sixty-day notice of intent to sue period has expired. Under Title VII the individual may not file suit until the EEOC notifies him that it has dismissed his complaint or has been unable to conciliate the dispute. ${ }^{76}$ After the EEOC has had the complaint for 180 days, the complainant may demand notice of his right to sue, ${ }^{77}$ and must bring suit within ninety days after receiving this notice. ${ }^{78}$

Even if the differences between the two Acts are ignored, Title VII precedent is of limited assistance. The Supreme Court, in apparently casual dicta, has characterized the Title VII requirements of timely filing with the EEOC and receipt of notice of right to sue as "jurisdictional prerequisites to a federal action" under the Act." The initial filing of a complaint with an appropriate state agency has also been characterized as a jurisdictional prerequisite to a Title VII suit..$^{80}$ However, these characterizations have not led to consistent decisions under Title VII. For example, in Reeb $v$. Economic Opportunity Atlanta, Inc. ${ }^{81}$ the Fifth Circuit held that the Title VII time limitations are not "inflexible 'jurisdictional' absolutes" but are subject to the equitable power of the courts. ${ }^{82}$ In Reeb, the court reasoned that the 180-day filing requirement did not begin to run until the plaintiff knew or should have known of her cause of action. Other courts have held that the filing period may be tolled while the aggrieved individual pursues remedies under a collective bargaining agreement. ${ }^{83}$ These inconsistent readings of Title VII's time periods

7642 U.S.C. $\$ 2000 \mathrm{e}-5(\mathrm{f})$ (1) (Supp. III 1973).

77 The regulations of the EEOC have construed the provision of 42 U.S.C. $\S 2000 \mathrm{e}-5(\mathrm{f})$ (Supp. III 1973) to require that after 180 days a notice of right to sue be issued upon the demand of the complainant. 29 C.F.R. $\S 1601.25 \mathrm{~b}(\mathrm{c})$ (1975). Before the 1972 amendments to Title VII, there was no provision for individual suit before the termination of EEOC proceedings. 42 U.S.C $\$ 2000 \mathrm{e}-5(\mathrm{e})(1970)$.

${ }^{78} 42$ U.S.C. $\S 2000 \mathrm{e}$ (f)(1) (Supp. III 1973). Cf. 29 U.S.C. $\S \S 625(\mathrm{e}), 255$ (1970) (ADEA statute of limitations).

79 McDonnell Douglas Corp. v. Green, 411 U.S. 792, 798 (1973) (dictum). See also Olson v. Rembrandt Printing Co., 511 F.2d 1228 (8th Cir. 1975); Moore v. Sunbeam Corp., 459 F.2d 811 (7th Cir. 1972); Choate v. Caterpillar Tractor Co., 402 F. 2d 357 (7th Cir. 1968).

so EEOC v. Union Bank, 408 F.2d 867 (9th Cir. 1968); Electrical Workers Local No. 5 v. EEOC, 398 F.2d 248 (3d Cir. 1968), cert denied, 393 U.S. 1021 (1969).

81 516 F.2d 924 (5th Cir. 1975).

82 Id. at 929.

s3 See Sanchez v. Trans World Airlines, Inc., 499 F.2d 1107 (10th Cir. 1974); Culpepper v. Reynolds Metals Co., 421 F.2d 888 (5th Cir. 1970). See also Alexander v. Gardner-Denver Co., 415 U.S. 36 (1974); see Comment, Limitations Periods for Filing a Charge with the Equal Employment Opportunity Commission Under Title VII of the Civil Rights Act of 1964, 56 B.U. L. REv. 70 (1976). 
and the differences in the ADEA's procedure and design support the Powell court's refusal to rest its analysis of the ADEA on the Title VII cases.

3. The Design and Purposes of the ADEA. The sparse legislative history and the indeteminate status of analogous procedural requirements under Title VII require an examination of the design and purposes of the ADEA, as suggested by the analysis in Burnett and American Pipe, ${ }^{84}$ in order to characterize the 180-day time limit. Some of the courts that term the time limit jurisdictional have undertaken this analysis. ${ }^{85}$ However, by treating the 180-day period as inseparable from the notice requirement, these cases have failed to consider the possibility that the 180 -day period was intended to serve a different purpose than the notice requirement.

In Burgett $v$. Cudahy Co.,$^{88}$ the district court focused on the ADEA's emphasis on "private settlement and the elimination of age discrimination without formal litigation." 87 The Secretary of Labor's initial exclusive jurisdiction over ADEA disputes, the court reasoned, is essential to the Act's goal of furthering private settlement and conciliation. The Secretary can "meaningfully exercise his conciliatory authority" only if he is "provided with notice of a violation and a reasonable length of time within which to seek elimination of the discriminatory practices." 88 Therefore, "the filing of a notice of intent to sue within one hundred and eighty days after a discriminatory act occurs and sixty days prior to the institution of an action, is a jurisdictional prerequisite to the maintenance of an action under the Act." 89 By viewing the sixty-day and the 180-day time limits as a single requirement designed to effectuate the grant of initial jurisdiction to the Secretary of Labor, the Burgett court never applied the Burnett and American Pipe analysis independently to the 180-day requirement. Even if the court is correct in arguing that the overall purpose and scheme of the ADEA can be effectuated only if the notice requirement is jurisdictional, no explanation is offered as to why the 180-day filing period is inseparable from the notice and sixty-day waiting period, or why it must also be jurisdictional. Indeed, the Burgett approach suggests that interpreting the sixty-day notice requirement as jurisdictional may be

st See text and notes at notes 31-35 supra.

as See, e.g., Powell v. Southwestern Bell Tel. Co., 494 F.2d 485 (5th Cir. 1974); Burgett v. Cudahy Co., 361 F. Supp. 617 (D. Kan. 1973).

s 361 F. Supp. 617 (D. Kan. 1973).

87 Id. at 621.

ss Id.

ss Id. at 621-22. 
sufficient to allow the Secretary an opportunity to reconcile the dispute through conciliation before private suit.

In Dartt v. Shell Oil Co. ${ }^{90}$ the Tenth Circuit focused on the role that the 180-day time limit plays apart from, or in addition to, the grant of initial jurisdiction to the Secretary of Labor. The court concluded that, while the notice of intent to sue is an absolute requirement, ${ }^{91}$ the time limit for filing the notice is subject to equitable modification..$^{92}$ Looking to section $626(\mathrm{~d})(1)$, the court found that

the two basic purposes behind the 180-day requirement are: (1) To provide the Labor Department with an opportunity to achieve a conciliation of the complaint while the complaint is still fresh, and (2) to give early notice to the employer of a possible lawsuit, the latter promoting both the preservation of evidence and good faith negotiating on the part of the employer during the conciliation period. ${ }^{93}$

The court determined that the plaintiff's actions had satisfied these purposes. ${ }^{94}$ The plaintiff had filed a complaint with the Department of Labor soon after her discharge, the Department had notified the employer of the allegations, and conciliation negotiations were begun. The plaintiff's failure to meet the filing deadline was the fault of the Department of Labor officials, who had not advised her of the requirement when she made her complaint, and of her employer, who had delayed giving the Department necessary information. In addition, the general notice of the ADEA provisions that had been supplied by the Department and posted by her employer was insufficient to inform her of the time limit..$^{95}$

${ }^{90} 539$ F.2d 1256 (5th Cir. 1976).

"Id. at 1260.

"Id. at 1259-61. The court rejected the plaintiff's alternative argument that a complaint to the Department of Labor that did not state an intent to sue was adequate to satisfy the notice requirement. Id. But see Woodford v. Kinney Shoe Corp., 369 F. Supp. 911 (N.D. Ga. 1973).

${ }^{23} 539$ F.2d at 1261.

" The court found that Dartt had been discharged on July 31,1973 , that she had filed a complaint with the Department of Labor shortly thereafter (August 9, 1973), and that a Department official was able to, and did, contact defendant Shell Oil on the same day the complaint was filed. Id. at 1258.

${ }^{95} 29$ U.S.C. $\$ 627$ (1970) provides:

Every employer, employment agency, and labor organization shall post and keep posted in conspicuous places upon its premises a notice to be prepared or approved by the Secretary setting forth information as the Secretary deems appropriate to effectuate the purposes of this chapter.

Although Shell had posted the notice which the Secretary provided, the court found this notice to be "completely inadequate to inform Dartt as to the 180 -day notice requirement." 539 F.2d at 1262. 
Since the plaintiff's delay was due to the fault of others and since the purpose of the requirement had been met, the court held that the time limit was tolled until the notice of intent to sue was filed. ${ }^{96}$ The court buttressed its analysis by looking to the general purposes of the ADEA. Noting that the Act was "remedial and humanitarian legislation," the court reasoned that the procedural requirements must be liberally interpreted in order to "effectuate the congressional purpose of ending age discrimination." "Judicial insistence on strict compliance with all the procedural requirements could frustrate this purpose since the substantive right conferred by the Act is often enforced by laymen. ${ }^{98}$ By examining the 180-day time limit in light of its role within the ADEA's procedural scheme and the broad purposes the Act is designed to serve, the Dartt court applied the analysis contemplated by Burnett and American Pipe.

The validity of the Dartt result can be tested by examining the effects of characterizing the 180-day time limit as jurisdictional or as nonjurisdictional. The Dartt court followed the judicial consensus $^{99}$ that the notice of intent to sue and the sixty-day waiting period are a single jurisdictional prerequisite. The purpose of vesting jurisdiction in the Secretary of Labor is to insure that age-based employment disputes will be settled informally whenever possible. The sixty-day time limit on the Secretary's exclusive jurisdiction provides an opportunity to attempt a conciliation without unduly delaying the complainant's access to the courts. While the goal of conciliation could be served regardless of when the Secretary learns of an aggrieved individual's intent to file suit, the 180-day time period makes the Secretary's intervention more effective. He receives prompt notice of alleged violations and can begin his investigation while the memories of the parties to the dispute are fresh, and evidence of the alleged discrimination, such as employment

" 539 F.2d at 1262.

"Id. at 1260. The ADEA's remedial character and the need to construe its provisions liberally have been accepted by other cases as well. See Moses v. Falstaff Brewing Corp., 525 F.2d 92 (8th Cir. 1975); Budreck v. Crocker Nat'l Bank, 407 F. Supp. 635 (N.D. Cal. 1976); Skoglund v. Singer Co., 403 F. Supp. 797 (D.N.H. 1975); Woodford v. Kinney Shoe Corp., 369 F. Supp. 911 (N.D. Ga. 1973).

ss 539 F.2d at 1260 . A similar rationale for liberal construction was advanced in Skoglund v. Singer Co., 403 F. Supp. 797 (D.N.H. 1975), and in Woodford v. Kinney Shoe Corp., 369 F. Supp. 911 (N.D. Ga. 1973). This line of reasoning was suggested by the Title VII cases, including Love v. Pullman Co., 404 U.S. 522 (1972), and Reeb v. Economic Opportunity Atlanta, Inc., 516 F.2d 924 (5th Cir. 1975).

" See notes 39, 91 supra. But see Eklund v. Lubrizol Corp., 529 F.2d 247 (6th Cir. 1976) (McCree, J., dissenting); Rucker v. Great Scott Supermarkets, 528 F.2d 393 (6th Cir. 1976) (McCree, J., concurring) (suggesting that none of the requirements of $\S 626$ (d) are jurisdictional). 
interview records, is still available. Early notice that the aggrieved individual intends to sue also guards against unfairness to employers and relieves them of the burden of defending stale claims.

Construing the period as a jurisdictional prerequisite clearly serves the purposes of preventing stale claims, preserving necessary evidence, and enhancing the Secretary's effectiveness in achieving informal conciliations. However, if the period is held to be outside the court's power to toll, waive, or estop, discriminatees may lose their ability to enforce their rights under the Act not because of their own delay, but due to the employer's fraud or negligence, or to the negligence of the Department of Labor. ${ }^{100}$ Section 627 of the ADEA attempts to aid victims of discrimination by requiring employers to post a notice provided or approved by the Department of Labor informing employees of their rights under the Act and the procedures for enforcing these rights. ${ }^{101}$ Although this provision partially

100 Statutes of limitations can be said primarily to promote fairness to defendants, and secondarily to promote judicial effectiveness by relieving the courts of the burden of adjudicating stale claims. See Developments, supra note 23, at 1185 . The ability of the courts to modify these time periods assures that they will not be used to block suits where the defendant has been the cause of the untimeliness or where the nature of the wrong was such that the plaintiff could not have learned of it until after the period had run. Jurisdictional time limits may also have the effect of protecting defendants and relieving the burden on the courts, but these are not the primary purposes. The inflexibility of jurisdictional prerequisites makes them ill-suited to further policies that may depend on the equities of a particular case. The major value of jurisdictional requirements is that they enable Congress to allocate the power to decide cases among various forums, thereby molding the power of the federal government for the best effectuation of congressional policies. For example, Congress may use such statutory requirements initially to channel controversies away from the courts to governmental bodies that it believes can resolve the conflict more satisfactorily. This appears to have been the case with the congressional grant of initial jurisdiction over labor disputes to the NLRB under the National Labor Relations Act, 29 U.S.C. $\$ \S 150-170,160(a)$,(d) (1970). Jurisdictional prerequisites should not function to preclude access to all forums in the event of noncompliance save for exceptional and limited areas of the law. One such exceptional area may involve the Federal Tort Claims Act, 28 U.S.C. $\S \S 1346,1402,1504,2110,2401$ (1970), pursuant to which courts have held that a plaintiff's strict compliance with the procedural requirements of the Act are a prerequisite to judicial acquisition of power to hear suits against the sovereign that would otherwise be barred by the doctrine of sovereign immunity. See, e.g., Simon v. United States, 244 F.2d 703 (5th Cir. 1957); Rauch v. Davis, 8 F.2d 907 (D.C. Cir. 1925). Waivers of sovereign immunity have traditonally been narrowly construed. United States v. Sherwood, 312 U.S. 584, 590-91 (1941); Eastern Transp. Co. v. United States, 272 U.S. 675,686 (1927). In cases where no such special consideration is present, it may be unreasonable to assume that Congress would seek to mold the jurisdiction of the courts in such a way that conscientious plaintiffs would be unable to enforce rights granted by Congress pursuant to a congressional policy, e.g., the elimination of age discrimination in employment, that can be enforced in no other forum. Courts should approach the problem of construing procedural requirements with the presumption that, where these requirements do not vest jurisdiction in another governmental body, Congress did not intend them to limit the subject matter jurisdiction of the courts.

${ }^{101}$ The text of $\S 627$ is provided at note 95 supra. 
meets the problem noted by the court in Dartt that the primary burden of enforcing $\mathrm{ADE}$ A rights rests on laymen, cases arising under the ADEA demonstrate that it is insufficient to safeguard an individual's opportunity to enforce his rights. ${ }^{102}$ If an employer deliberately or negligently fails to post the section 627 notice, his employees may be unaware that they have a remedy for age-based discrimination until after the 180-day period has expired. ${ }^{103}$ Even if this notice provision is met, an employer may lead his employee to believe incorrectly that he or she has not been the subject of special, age-based treatment, and the employee may not discover the true state of affairs for more than 180 days. ${ }^{104}$ An employer could also induce his employee to delay in filing a notice of intent to sue by falsely promising compensation for the employee's loss. ${ }^{105}$ Furthermore, as the Dartt case illustrates, negligent mishandling of complaints by the Department of Labor may cause an individual to fail to provide notice of intent to sue within the 180-day period. If an individual takes his grievance to the Department and is not advised of the necessary procedural steps to bring his case to court, he may miss timely filing of his formal notice of intent to sue. Even if the individual knows the Act's requirements through a section 627 notice posted by his employer, a Labor Department official may lead him to believe that his complaint, even if oral and without a specific mention of his intent to sue, has met the requirements of the Act. ${ }^{106}$ If the courts are without power to toll or waive the 180-day period in such circumstances, discriminators could easily avoid any sanctions under the Act.

When a plaintiff has failed to meet the time limit through the fault of others, the courts have usually avoided the harsh results that should logically follow the characterization of the 180-day requirement as jurisdictional. While terming the time limit jurisdictional, the courts have weighed the plaintiff's interest in attempting to vindicate his rights under the Act against the defendant's burden in litigating an untimely suit, thus treating the time limit as analogous to a statute of limitations. ${ }^{107}$ This approach has resulted in

ive See, e.g., Dartt v. Shell Oil Co., 539 F.2d 1256 (10th Cir. 1976), cert. granted, 97 S. Ct. 1097 (1977).

ios See Edwards v. Kaiser Aluminum \& Chem. Sales, Inc., 515 F.2d 1195 (5th Cir. 1975) (dictum). But see Hiscott v. General Elec. Co., 521 F.2d 632, 634 (6th Cir. 1975); Brohl v. Singer Co., 407 F. Supp. 936 (M.D. Fla. 1976).

10 See McGinley v. Burroughs Corp., 407 F. Supp. 903 (E.D. Pa. 1975).

${ }_{105}$ See Hiscott v. General Elec. Co., 521 F.2d 632 (6th Cir. 1975).

${ }_{100}$ See Woodford v. Kinney Shoe Corp., 369 F. Supp. 911 (N.D. Ga. 1973).

${ }_{107}$ See id. (holding substantial compliance with the notice requirement sufficient where Department of Labor negligently failed to inform plaintiff of the requirement that she file 
conceptual confusion, disharmony among the courts, and unpredictable law. Frankly acknowledging that the 180-day period is to be treated as a statute of limitations would alleviate this confusion. Furthermore, the purposive analysis suggested by the Supreme Court in Burnett and American Pipe supports this interpretation of the time limit. The ability of conscientious plaintiffs to enforce their rights should not turn on the ability of the courts to manipulate the jurisdictional period. Rather, the courts should be able to resolve problems of untimeliness in light of traditional equitable principles. ${ }^{108}$ Construing the 180 -day time period as a statute of limitations would maintain its role of precluding stale claims and preserving fresh evidence without allowing alleged discriminators to escape sanction under the Act. The improved effectiveness of the Act's enforcement mechanism, as well as the increased consistency and predictability of ADEA cases, strongly support the Dartt court's conclusion that Congress did not intend the 180-day requirement to be jurisdictional.

written notice of her intent to file suit); Edwards v. Kaiser Aluminum \& Chem. Sales, Inc., 515 F.2d 1195 (5th Cir. 1975) (dictum suggesting that 180-day period may be tolled where employer has failed to post notice of ADEA required by 29 U.S.C. $\$ 627$ (1970)); Bishop v. Jelleff Assocs., Inc., 398 F. Supp. 579 (D.D.C. 1974) (holding oral complaint to Department of Labor sufficient to maintain action where employer failed to post notice required by 29 U.S.C. § 627 (1970)). But see Powell v. Southwestern Bell Tel. Co., 494 F.2d 485 (5th Cir. 1974).

${ }^{103}$ Equitable principles such as estoppel and tolling will not answer all the questions that may arise in applying the 180 -day requirement. Two situations may cause particular difficulty. Where the plaintiff's tardiness is due to the mishandling of his complaint by the Department of Labor, see, e.g., Dartt v. Shell Oil Co., 539 F.2d 1256 (10th Cir. 1976), cert. granted, 97 S. Ct. 1097 (1977), a court must balance the plaintiff's interest in obtaining a remedy against the interests of the employer that the requirement is designed to protect. Where an employer has posted a $\S 627$ notice and has not attempted to interfere with his employee's recourse under the Act, it may be unfair to deprive him of the protection of the 180-day period because of the negligence of the Department of Labor. This problem did not appear in Dartt because the employer had contributed to the Department's mishandling of the complaint and had posted an inadequate notice.

A second problem arises where the plaintiff has pursued collective bargaining grievance procedures for more than 180 days. This problem has been a source of conflict under Title VII. In Alexander v. Gardner-Denver Co., 415 U.S. 36 (1974), the Supreme Court held that where an aggrieved individual has initially prusued his collective bargaining grievance procedures, he is not barred from filing an action under the Title. The circuits have split over whether Gardner-Denver means that Title VII time limits will be tolled during pursuit of collective bargaining grievance procedures. See Guy v. Robbins \& Myers, Inc, 525 F.2d 124 (6th Cir. 1975), cert. granted, 96 S. Ct. 1723 (1976) (holding that filing of a grievance does not toll the running of the EEOC filing limitation period); contra, Sanchez v. Trans World Airlines, Inc., 499 F.2d 1107 (10th Cir. 1974); Note, Jurisdictional Prerequisites to Private Actions Under Title VII of the Civil Rights Act of 1964, 41 Mo. L. Rev. 215, 222-25 (1976). 


\section{Section 633}

Section $633^{109}$ of the ADEA regulates the impact of the federal law of age discrimination in employment on similar state and local laws. The section gives state officials a sixty-day period in which to attempt to resolve an age-based employment dispute before they are preempted by a federal suit. Some courts have held that the provision requires individuals in states with age discrimination laws to file a complaint with the appropriate state agency, ${ }^{110}$ raising the question whether this requirement is a jurisdictional prerequisite to suit or subject to waiver. ${ }^{111}$ Other courts have concluded that the section is designed to give state officials a sixty-day period in which to act before federal suit can be brought only if the aggrieved individual has chosen to bring his complaint to the state as well as to the Department of Labor. ${ }^{112}$ This interpretation creates a question concerning the construction of section 626(d)(2), which modifies the 180-day time limit by requiring plaintiffs in cases "to which section $633(\mathrm{~b})$. . . applies" to file notice with the Secretary within 300 days of the alleged violation or within thrity days of the termination of state proceedings, whichever is earlier. ${ }^{113}$ The courts must decide whether an individual who resides in a state with age discrimination laws may receive the benefit of the expanded filing period even if he has not filed a state complaint.

Title VII is more significant for the interpretation of section 633 of the ADEA than for the interpretation of section 626. The Title VII federalism provision, section $2000 \mathrm{e}-5$ (c),${ }^{114}$ has been construed to

109 The text of $\S 633$ is provided at note 10 supra.

wo E.g., Eklund v. Lubrizol Corp., 529 F.2d 247 (6th Cir. 1976); Curry v. Continental Airlines, 513 F.2d 691 (9th Cir. 1975); Goger v. H.K. Porter Co., 492 F.2d 13 (3d Cir. 1974); Smith v. Crest Communities, Inc., 9 Empl. Prac. Dec. 7334 (W.D. Ky. 1974).

III See Bertrand v. Orkin Exterminating Co., 419 F. Supp. 1123, 1125 (N.D. I1l. 1976) (dictum); Smith v. Jos. Schlitz Brewing Co., 419 F.Supp. 770 (D.N.J. 1976); Skoglund v. Singer Co., 403 F. Supp. 797 (D.N.H. 1975).

112 Bertrand v. Orkin Exterminating Co., 419 F. Supp. 1123 (N.D. Ill. 1976) (dictum); Vazquez v. Eastern Airlines, Inc., 405 F. Supp. 1353 (D.P.R. 1975); Goger v. H.K. Porter Co., 492 F.2d 13, 17 (3d Cir. 1974) (Garth, J., concurring).

${ }^{113}$ The text of $\S 626(\mathrm{~d})(2)$ is provided at note 9 supra.

11442 U.S.C. $\$ 2000$ e-5(c) (Supp. III 1973) provides:

In the case of an alleged unlawful employment practice occurring in a State, or political subdivision of a State, which has a State or local law prohibiting the unlawful employment practice alleged and establishing or authorizing a State or local authority to grant or seek relief from such practice or to institute criminal proceedings with respect thereto upon receiving notice thereof, no charge may be filed under subsection (b) of this section by the person aggrieved before the expiration of sixty days after proceedings have been commenced under the State or local law, unless such proceedings have been earlier terminated....

This section was denominated $\S 2000 \mathrm{e}-5$ (b) before the 1972 amendments to Title VII. See also 
require individuals to file complaints with appropriate state authorities before seeking federal relief, ${ }^{115}$ an interpretation strongly supported by the legislative history. ${ }^{116}$ Several of the courts that have considered the ADEA federalism provision have found its similarity to Title VII indicative of a congressional intent that it have an identical meaning. ${ }^{17}$ The Third Circuit, in Goger v. H.K. Porter Co. ${ }^{118}$ buttressed the argument from the similar language of the two provisions by reference to the legislative history of the ADEA. ${ }^{119}$

Other courts have found the ADEA provision distinguishable from the Title VII provision and thus open to different interpretation. ${ }^{120}$ The courts in Vazquez $v$. Eastern Airlines, Inc. ${ }^{121}$ and Bertrand $v$. Orkin Exterminating $\mathrm{Co}^{122}$ advanced three grounds for distinguishing between the ADEA provision and its Title VII counterpart: the ADEA provision must be construed in the context of its distinctly different procedural scheme; ${ }^{123}$ the isolation of the ADEA federalism provision from the procedural requirements of the Act is probative evidence that Congress did not intend to make filing with the state a condition to federal suit under the ADEA; ${ }^{124}$ and the

42 U.S.C. 2000e-5(d) (Supp. III 1973), which governs deferral when the EEOC itself initiates proceedings.

115 Love v. Pullman Co., 404 U.S. 522 (1972); Crosslin v. Mountain States Tel. \& Tel. Co., 422 F.2d 1028, vacated, 400 U.S. 1004 (1971); EEOC v. Union Bank, 408 F.2d 867 (9th Cir. 1968); Stebbins v. Nationwide Mut. Ins. Co., 382 F.2d 267(4th Cir. 1967), cert. denied, 390 U.S. 910 (1968); Ethridge v. Rhodes, 268 F. Supp. 83 (S.D. Ohio 1967).

${ }^{11}{ }^{S}$ See, e.g., 110 CoNG. REc. 12,721 (1964). Senator Humphrey remarked: "If the practice complained of occurs in a State or locality which has a law prohibiting such practices and establishing an agency to deal with them ... the individual complainant cannot file his charge with the Commission until the State or local agency has been given an opportunity to handle the problem under State or local law. However, after the agency has had 60 days to adjust the complaint, or after it terminates proceedings on it, the complainant may go to the Federal Commission." Id.

11 Curry v. Continental Airlines, 513 F.2d 691 (9th Cir. 1975); Goger v. H.K. Porter Co. 492 F.2d 13 (3d Cir. 1974); McGarvey v. Merck \& Co., 359 F. Supp. 525 (D.N.J. 1973), vacated, 493 F.2d 1401 (3d Cir.), cert. denied, 419 U.S. 836 (1974).

118492 F.2d 13 (3d Cir. 1974).

11 During the course of hearings on the ADEA, Congress was advised to adopt the federalism arrangements of Title VII. Goger v. H.K. Porter Co., 492 F.2d 13, 16 n.13 (3d Cir. 1974) (citing statements by Andrew J. Biemiller, Legislative Director of the AFL-CIO, and J. Edward Conway, New York State Commission for Human Rights).

120 Bertrand v. Orkin Exterminating Co., 419 F. Supp. 1123 (N.D. Ill. 1976) (dictum); Vazquez v. Eastern Airlines, Inc., 405 F. Supp. 1353 (D.P.R. 1975); Goger v. H.K. Porter Co., 492 F.2d 13, 17 (3d Cir. 1974) (Garth, J., concurring).

121405 F. Supp. 1353 (D.P.R. 1975).

122419 F. Supp. 1123 (N.D. Ill. 1976).

123 Id. at 1126-27; Vazquez v. Eastern Airlines, Inc., 405 F. Supp. 1353, 1354-55 (D.P.R. 1975).

${ }^{124}$ Bertrand v. Orkin Exterminating Co., 419 F. Supp. 1123, 1126-27 (N.D. Ill. 1976); Vazquez v. Eastern Airlines, Inc., 405 F. Supp. 1353, 1355 (D.P.R. 1975). 
addition of subsection 633 (a) significantly alters the meaning of the language borrowed from Title VII and embodied in subsection 633(b) of the ADEA. ${ }^{125}$

In Vazquez the court looked to Congress's rejection of the Title VII procedural scheme for the ADEA and concluded that to follow the Title VII precedents and construe the ADEA federalism provision as requiring state filing would "create a procedural pitfall for unsuspecting individuals which could easily serve . . . to deprive aggrieved individuals of their day in court . . . ."126 However, congressional dissatisfaction with the procedure of Title VII, in part based on the delays it had engendered, ${ }^{127}$ does not necessarily demonstrate dissatisfaction with the Title VII federalism provisions. The Third Circuit in Goger v. H.K. Porter Co. ${ }^{128}$ argued that the legislative history of the ADEA and the adoption of Title VII language in section 633 support an inference of congressional satisfaction with the Title VII federalism provision. ${ }^{129}$ The desire to avoid trespassing into areas of legitimate state concern where the states have acted or are encouraged to act may, as under Title VII, outweigh Congress's concern to design the enforcement provision of the Act to operate as efficiently as possible.

The other arguments advanced by Bertrand and Vazquez focus on differences between the Title VII provision and section 633. The first of these arguments, that substantial weight should be attached to the section's location within the ADEA, ${ }^{130}$ fails to dispose of the presumption of similar meaning raised by the similar language. That Congress sought to make a fundamental change in meaning simply by shifting the location of the provision is highly doubtful. It may be significant that, while the Title VII federalism provision is contained among the procedural requirements of that Act, the ADEA provision stands apart. However, the significance of a change in the location of the provision is uncertain unless its language indicates that Congress intentionally "relocated" it because it was no longer appropriate to place it among the procedural requirements of the ADEA.

${ }^{125}$ Bertrand v. Orkin Exterminating Co., 419 F. Supp. 1123, 1127 (N.D. Ill. 1976); Vazquez v. Eastern Airlines, Inc., 405 F. Supp. 1353, 1356 (D.P.R. 1975).

128405 F. Supp. at 1357.

127 Id. at 1355 .

123492 F.2d 13 (3d Cir. 1974).

123 429 F.2d at 16. This inference is buttressed by the fact that when Title VII was amended in 1972, Congress retained the original state-federal provision. Compare 42 U.S.C. $\S 2000 \mathrm{e}-5(\mathrm{~b})$ (1970) with 42 U.S.C. § 2000e-5(c) (Supp. III 1973).

130 Bertrand v. Orkin Exterminating Co., 419 F. Supp. 1123, 1126-27 (N.D. Ill. 1976). 
The strongest distinction from Title VII is the addition of subsection 633(a) to the body of the Title VII "model"-a highly significant change in the language of the provision. This subsection provides that

[n]othing in this chapter shall affect the jurisdiction of any agency of any State performing like functions with regard to discriminatory employment practices on account of age except that upon commencement of action under this chapter such action shall supersede any State action. ${ }^{131}$

Judge Garth, concurring in Goger v. H.K. Porter Co., ${ }^{132}$ found it unbelievable that Congress intended to require as a precondition to federal suit "the commencement of a State proceeding which, under $\S 633(\mathrm{~b})$, need not be concluded and which in any event would be superseded by the filing of a Federal action under $§ 633(a) .{ }^{\prime \prime 33}$ Part of this argument would apply to the Title VII federalism procedure as well, since that section appears to require only that state proceedings be initiated, not completed; but Title VII contains no provision analogous to section 633(a) that would require a stay of state proceedings on commencement of a federal action. ${ }^{134}$

Furthermore, section 633 differs from Title VII in an aspect the courts have ignored. Section 2000e-5(c) of Title VII places a moratorium on all initiation of federal action by individuals for sixty days after state proceedings have begun by prohibiting individuals from filing a charge with the EEOC before the end of that time. During the two-month period state officials can seek resolution under state law with exclusive power to negotiate with the alleged discriminator, to examine his records, and to compile evidence. ${ }^{135}$ Under section 633 of the ADEA, on the other hand, the aggrieved individual is simply prohibited from filing suit during the sixty-day period. Apparently, an individual could file state charges and notify the

13129 U.S.C. $\$ 633(a)$ (1970).

is2 492 F.2d 13, 17 (3d Cir. 1974) (Garth, J., concurring).

${ }^{133} I d$. at 18.

134 While the Title VII requirement has been characterized as an "exhaustion" requirement, EEOC v. Union Bank, 408 F.2d 867, 869-70 (9th Cir. 1968), it seems to mean no more than that state proceedings must be begun.

See Developments in the Law-Employment Discrimination and Title VII of the Civil Rights Act of 1964, 84 HARv. L. REv. 1109, 1212 (1971) ("There is, however, no requirement that state remedies be exhausted. State proceedings need only be commenced; at any time after sixty days, the complainant may file charges with the EEOC, whether or not the state agency has completed its action on the case. The state and federal authorities then proceed side by side.").

${ }^{135}$ States also have the power to delay actions initiated by the EEOC itself for sixty days while a state proceeding is in progress. See 42 U.S.C. $§ 2000$ e-5(d) (Supp III 1973). 
Secretary of Labor of the violation on the same day and file his federal suit sixty days later. ${ }^{136}$ This would mean that the Department of Labor would begin and conduct its investigation contemporaneously with state authorities. Thus, in contrast to Title VII, the ADEA does not give exclusive jurisdiction to state agencies for the sixty-day period.

In light of these distinguishing characteristies of the ADEA provisions, to interpret section 633 to require individuals to file state complaints reads a burdensome formality into the Act. Mandatory state filing would force aggrieved individuals to file a state complaint concurrently with their federal complaint, even when they had no interest in obtaining a state remedy. Once the individual complies with the requirement by filing a state complaint, he may have little incentive to cooperate with state officials, particularly if the state remedy is less attractive than federal remedies. State officials would also have little incentive to act on such pro forma complaints. If state officials did act on a complaint concurrently with the federal authorities, defendants and witnesses would be burdened by the demands of two separate investigations. In addition, the defendant's incentive to cooperate with state officials would be hampered by subsection 633(a)'s provision that any state action will be superseded by a federal action.

Interpreting section 633 to require state filing would not strengthen state age discrimination laws or facilitate the efforts of the state agencies charged with their implementation. Rather, such a requirement would frustrate state efforts by burdening state officials with insincere complaints and investigations that might be ultimately superflous if superseded by federal intervention.

The construction adopted by Judge Garth's concurrence and the court in Vazquez, leaving to aggrieved individuals the choice whether to pursue state remedies, is more satisfactory. Reading the provision as elective may encourage states to develop age discrimination laws that are equal or superior to the federal law as an incentive for its citizens to choose to file state complaints. ${ }^{137}$ The provision would then give substance to their election by giving state officials

13 Contra, Vaughn v. Chrysler Corp., 382 F. Supp. 143, 145 (E.D. Mich. 1974). The district court interpreted the section to require that individuals wait sixty days after filing state complaints before giving the Secretary notice of intent to file suit. This interpretation is unsupported by the language of the section.

137 The legislative history supports this interpretation. See Vazquez v. Eastern Airlines, Inc., 405 F. Supp. 1353, 1356 (D.P.R. 1975), citing Hearings Before the Subcomm. on Labor of the Senate Comm. on Labor and Public Welfare on S. 830 and S. 788, 90th Cong., 1st Sess. 48 (1967) (testimony of Secretary Wirtz). 
sixty days to act before a federal suit could be brought. If the complainant is genuinely interested in obtaining the state remedy, he will work with state officials. The aggrieved individual would not be required to file his federal notice of intent to sue for 300 days after the alleged violation; ${ }^{138}$ he could rely exclusively on state law for that period. Section 633 of the ADEA can therefore be sensibly interpreted as designed to encourage states to develop age discrimination laws that can "compete" effectively with the federal law.

Interpreting section 633 to make the filing of a state complaint elective raises a question about the scope of section $626(\mathrm{~d})(2)$ of the ADEA. ${ }^{130}$ This section provides that "in a case to which section 633(b) of this title applies," the ADEA complainant has 300 rather than 180 days in which to file his notice of intent to sue in federal court. The Sixth Circuit has held that in order to qualify for this expanded filing period, two conditions must be met: first, the state in which the complainant resides must have a state age discrimination in employment law; and, second, the state must have an agency expressly authorized to grant or seek relief under the law. ${ }^{140}$ If these are the only conditions on the expanded filing period, individuals residing in states with such laws and agencies would enjoy an arbitrary procedural advantage over those individuals who reside in states without age discrimination in employment laws. It seems unlikely that this is the result intended by Congress. The preferable interpretation of section $626(\mathrm{~d})(2)$ is that a third condition must be met in order to make section 633(b) applicable: the individual must have elected to commence state proceedings. This allows individuals to use available state remedies without jeopardizing their federal rights, but does not give an unnecessary benefit to individuals who bypass state laws and proceed directly to the federal procedures. ${ }^{141}$

\section{Conclusion}

The problems of interpretation that have arisen in connection

1389 U.S.C. \& 626(d) (1970); see note 9 supra.

133 29 U.S.C. $\$ 626$ (d)(2) (1970); see note 9 supra.

1to Eklund v. Lubrizol Corp., 529 F.2d 247 (6th Cir. 1976).

i' Where the individual has filed a state complaint, the sixty-day deferral period, like the sixty-day notice of intent to sue requirement, limits the jurisdiction of the federal courts. If an individual attempts to file suit before the end of the state deferral period, the courts should adopt the "suspended animation" doctrine developed under Title VII to deal with complaints filed prematurely with the EEOC. Under this doctrine, a complaint is referred to the state authority. At the end of the sixty-day deferral period, the complaint is treated as automatically filed with the federal agency. This practice was upheld under Title VII procedures in Love v. Pullman Co., 404 U.S. 522 (1972). 
with the procedural requirements of the ADEA can be satisfactorily resolved only by analyzing the functions of those requirements in the Act, a method suggested by the Supreme Court as appropriate for construing statutory time limits, and profitably applied to the ADEA problems in Dartt $v$. Shell Oil Co. The requirement that notice of intent to sue be filed with the Secretary of Labor within 180 days after the alleged discrimination occurred effectuates the overall purposes and remedial scheme of the Act if understood as a statute of limitations and therefore subject to equitable modification. The federalism provision of the Act does not require complaints to be filed with state authorities, but when such complaints are filed, the federal courts have no power to entertain suit under the Act until sixty days have expired from commencement of state proceedings. Finally, section $626(\mathrm{~d})(2)$ of the Act should be interpreted to afford an expanded filing period only to individuals who have filed initial complaints with appropriate state authorities. These interpretations respond to the need for an efficient procedural mechanism without jeopardizing the substantive rights and federalism concerns that underlie the statute. 